\title{
Dab2IP Regulates Neuronal Positioning, Rap1 Activity and Integrin Signaling in the Developing Cortex
}

\author{
Shuhong Qiao Ramin Homayouni \\ Department of Biological Sciences, University of Memphis, Memphis Tenn., USA
}

\section{Key Words}

GTPase activating protein · Migration · Rap1GAP · RasGAP · Reelin

\begin{abstract}
Dab2IP (DOC-2/DAB2 interacting protein) is a GTPase-activating protein which is involved in various aspects of brain development in addition to its roles in tumor formation and apoptosis in other systems. In this study, we carefully examined the expression profile of Dab2IP and investigated its physiological role during brain development using a Dab2IPknockdown (KD) mouse model created by retroviral insertion of a LacZ-encoding gene-trapping cassette. LacZ staining revealed that Dab2IP is expressed in the ventricular zone as well as the cortical plate and the intermediate zone. Immunohistochemical analysis showed that Dab2IP protein is localized in the leading process and proximal cytoplasmic regions of migrating neurons in the intermediate zone. Bromodeoxyuridine birth dating experiments in combination with immunohistochemical analysis using layer-specific markers showed that Dab2IP is important for proper positioning of a subset of layer II-IV neurons in the developing cortex. Notably, neuronal migration was not completely disrupted in the cerebral cortex of Dab2IP-KD mice and disruption of migration was not strictly layer specific. Previously,
\end{abstract}

we found that Dab2IP regulates multipolar transition in cortical neurons. Others have shown that Rap1 regulates the transition from multipolar to bipolar morphology in migrating postmitotic neurons through $\mathrm{N}$-cadherin signaling and somal translocation in the superficial layer of the cortical plate through integrin signaling. Therefore, we examined whether Rap1 and integrin signaling were affected in Dab2IP-KD brains. We found that Dab2IP-KD resulted in higher levels of activated Rap1 and integrin in the developing cortex. Taken together, our results suggest that Dab2IP plays an important role in the migration and positioning of a subpopulation of later-born (layers II-IV) neurons, likely through the regulation of Rap1 and integrin signaling.

(c) 2015 S. Karger AG, Basel

\section{Introduction}

The mammalian neocortex has a highly organized sixlayered structure containing different types of neurons arranged in stereotypical patterns [1]. Neuronal migration plays an essential role in the development of this laminar structure. At early stages of neocortical development, migrating neurons enter the cortical plate via glial-independent somal translocation $[2,3]$. Later-born neurons migrate further distances using several modes of migra-

\section{KARGER 125}

(c) 2015 S. Karger AG, Base

0378-5866/15/0372-0131\$39.50/0

E-Mail karger@karger.com

www.karger.com/dne
Ramin Homayouni

Department of Biological Sciences

University of Memphis

201 Life Science Building, Memphis, TN 38152 (USA)

E-Mail rhomayon@memphis.edu. 
tion. First, postmitotic neurons move radially to the subventricular zone and lower intermediate zone, where they become multipolar $[3,4]$. Next, the newly born neurons become bipolar by extending a leading process and a trailing axon while retracting other neurites $[5,6]$. These bipolar-shaped neurons migrate long distances along the radial glial fibers to the upper part of the cortical plate [2, 5]. Finally, migrating neurons attach their leading processes to the marginal zone and switch to a glial-independent terminal translocation mode to position themselves beneath the outermost region of the cortical plate $[7,8]$.

Several signaling pathways have been shown to regulate various aspects of neuronal migration in the developing mammalian cortex. Reelin is a large extracellular glycoprotein secreted by Cajal-Retzius cells in the marginal zone that controls both early and late events in cortical development. Mutations in the Reelin signaling pathway (including lipoprotein receptors ApoER2/VLDLR and Dab1 cytosolic adapter protein) disrupt early splitting of the cortical plate in addition to migration and positioning of early- and late-born neurons [9-12]. Upon Reelin-induced tyrosine phosphorylation, Dab1 binds to the $\mathrm{p} 85$ regulatory subunit of PI3K and CrkL, and C3G, a Rap1 guanine nucleotide exchange factor (GEF) $[13,14]$. Recent reports suggest that Rap1 plays an important role in neuronal migration by regulating $\mathrm{N}$-cadherin-mediated adhesion required for multipolar to bipolar transition [7, $15]$ and integrin-mediated adhesion required for terminal somal translocation $[16,17]$.

We initially found Dab2IP (DOC-2/DAB2 interacting protein) by virtue of its interaction with Dab1 in a yeast two-hybrid screen [18]. Dab2IP, also known as ASK1 (apoptosis signal-regulating kinase-interacting protein-1), is a GTPase-activating protein associated with aggressive metastatic prostate cancer [19], abdominal aortic aneurysms [20] and coronary heart disease [21]. Dab2IP was shown to inhibit Ras, JNK (c-Jun kinase) and PI3KAKT signaling pathways and to regulate mesenchymalto-neuroepithelial transition of stem cells [22-25]. Recently, we and others have shown that Dab2IP is expressed in a variety of neurons in the brain and plays a role in the regulation of synaptogenesis, dendritic morphogenesis, neuronal differentiation and migration [24, 26, 27]. In utero knockdown (KD) of Dab2IP by siRNA disrupted the transition of migrating neurons from multipolar to bipolar morphology in the developing neocortex [26]. In this study, we carefully examined the role of Dab2IP in the neuronal migration and lamination of the cortex using a mouse model with Dab2IP expression KD by a retroviral gene trap strategy.

\section{Materials and Methods}

\section{Animals}

All mice used in this study were maintained in certified animal facilities at the University of Memphis and all experiments were performed in accordance with the institutional guide for animal care using an animal protocol (protocol No. 0644, December 20, 2012) approved by the University of Memphis Institutional Animal Care and Use Committee. Mice were housed with unlimited access to water and food under a 12-hour-light/12-hour-dark day cycle. Throughout all experimental procedures, efforts were made to minimize the number of animals used and their suffering. Generation of Dab2IP-KD [Dab2IPGt(OST348452)Lex] mice with C57/B6 background was described previously [27].

\section{Histology and Immunohistochemistry}

Mice were perfused with $4 \%$ paraformaldehyde, and the brains were removed and postfixed for $3 \mathrm{~h}$ in $4 \%$ paraformaldehyde. Brains from embryonic mice were fixed in $4 \%$ paraformaldehyde without perfusion. The fixed brains were cryoprotected with $30 \%$ sucrose, embedded in tissue freezing medium (OCT), frozen in isopentane cooled with liquid nitrogen and sectioned using a Leica cryostat (CM3050).

For X-gal staining, embryos or postnatal mice which were heterozygous for the retroviral gene trap cassette in Dab2IP intron 5 were perfused and embedded as above. Cryosections $(12 \mu \mathrm{m})$ were washed 3 times in solution $\mathrm{C}(137 \mathrm{mM} \mathrm{NaCl}, 2.7 \mathrm{mM} \mathrm{KCl}$, $10 \mathrm{mM} \mathrm{Na}_{2} \mathrm{HPO}_{4}, 2 \mathrm{mM} \mathrm{KH} \mathrm{PO}_{4}, 2 \mathrm{mM} \mathrm{MgCl}$, $5 \mathrm{mM}$ EGTA, $0.02 \%$ IGEPAL and $0.01 \%$ sodium desoxycholate) and incubated overnight in X-gal staining solution (solution $\mathrm{C}+10 \mathrm{mM} \mathrm{K}_{3} \mathrm{FeCN}_{6}$,

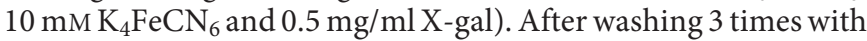
$1 \times$ PBS, sections were visualized with nuclear Fast Red counterstaining.

For immunohistochemical staining, coronal sections $(12 \mu \mathrm{m})$ were incubated overnight at $4^{\circ} \mathrm{C}$ with the following primary antibodies: anti-CuX1 (1:1,000, rabbit; Santa Cruz), anti-Tbr1 (1:500, rabbit; Abcam), anti-Brn 2 (1:500, rabbit; Abcam), anti-bromodeoxyuridine (BrdU; 1:500, mouse; Millipore), anti-Dab2IP (1:2,000-1:4,000, rabbit) and anti-CSPG (1:1,000; Sigma). After washing in $1 \times$ PBS, sections were incubated with Alexa Fluor (Invitrogen) conjugated secondary antibodies $(1: 2,000)$, and images were collected using confocal laser scan microscopy (Nikon A1) at the Integrated Microscopy Center at the University of Memphis.

\section{BrdU Birth Dating Analysis}

Heterozygous Dab2IP ${ }^{\mathrm{Gt}(\mathrm{OST} 348452) \mathrm{Lex}}$ were mated and the pregnant mothers were injected intraperitoneally with BrdU (SigmaAldrich) dissolved in $0.9 \% \mathrm{NaCl}, 50 \mathrm{mg} / \mathrm{kg}$ body weight at either E12.5 or E16.5. The age of embryos was calculated from noon on the day of the vaginal plug, which was set at embryonic day 0.5 (E0.5). Cryosections from postnatal day 21 (P21) pups were incubated in $2 \mathrm{~N} \mathrm{HCL}$ for $30 \mathrm{~min}$ at room temperature to denature DNA, neutralized for 5 min with $0.1 \mathrm{M}$ sodium borate buffer $(\mathrm{pH}$ 8.5 and subsequently stained with BrdU.

Primary Culture

E14 mouse embryonic cerebral cortices were treated with $0.25 \%$ Trypsin-EDTA for $20 \mathrm{~min}$ at $37^{\circ} \mathrm{C}$ and dissociated into single cells by gentle trituration. Cells were suspended in Neurobasal 
medium (Invitrogen) supplemented with B27 (Invitrogen) and $2 \mathrm{mM}$ L-glutamine, and then seeded on poly-D-lysine-coated cover slides. After a 3 -hour incubation at $37^{\circ} \mathrm{C}$, cells were fixed with $2 \%$ paraformaldehyde in PBS for 20 min and stained with anti-Dab2IP $(1: 4,000)$ plus rhodamine-phalloidin antibody (1:2,000; Millipore).

\section{Immunoblotting}

Brains were dissected and homogenized in lysis buffer containing 0.05\% NP40, $150 \mathrm{~mm} \mathrm{NaCl}, 50 \mathrm{~mm}$ Tris- $\mathrm{HCl}$ (pH 7.4), $10 \%$ glycerol, EDTA-free protease inhibitor cocktail (Roche) and a phosphatase inhibitor mixture PhosSTOP (Roche). Protein amounts were quantified using a BCA protein assay kit (Pierce), and an equal amount of protein was loaded for each sample, separated by SDS-PAGE and transferred onto PVDF membranes. Membranes were then subjected to immunoblot analysis using anti-Dab2IP (1:5,000), anti-actin (Sigma), anti-Rap1 (1:1,000; Thermo Scientific) and anti-integrin (9EG7, 1:1,000; BD Pharmingen) antibodies. Proteins were visualized using Super Signal West Pico or Femto reagents (Thermo Scientific). For quantitative analysis of Western blotting results, X-ray films were scanned and densitometric analysis was performed using NIH ImageJ software.

Ras and Rap1 Activation Assay

Activated Ras or Rap1 levels were assayed with the active Ras or Rap1 pull-down and detection kit from Thermo Scientific following the manufacturer's protocol. In brief, brain lysates $(1,000$ $\mu \mathrm{g}$ total protein) from E16 wild-type (WT) and Dab2IP-KD cerebral cortices were incubated with GST-Raf1-RBD or GST-RalGDS-RBD fusion protein for $2 \mathrm{~h}$ at $4^{\circ} \mathrm{C}$ on a rotating platform. The GTP-bound Ras or Rap1 (active form) was affinity precipitated, washed and then eluted with $50 \mu \mathrm{l}$ SDS sample buffer by boiling for $5 \mathrm{~min}$. The amount of GTP-bound Ras or Rap1 was analyzed by SDS-PAGE followed by immunoblotting using the anti-Ras or -Rap1 antibody included in the kit.

\section{Results}

Expression of the Dab2IP Gene in the Cerebral Cortex during Development

Dab2IP appears to be exclusively expressed in neurons in various brain structures [27]. Previously, we found that multiple isoforms of Dab2IP protein exist in the adult cerebellum [27]. Here, we investigated the temporal and spatial expression patterns of Dab2IP in the developing cortex using different approaches. Immunoblot analysis was performed on lysates prepared from telencephalon (E12) and cortex (E16, P0 and P30) of C57/B6 mice. Dab2IP protein was observed as early as E12 in the telencephalon (fig. 1A). Multiple Dab2IP isoforms were observed at all stages, but their relative levels differed during development. At P30, three major isoforms of Dab2IP protein were detected, similar to our previous observations in the cerebellum [27]. Multiple isoforms of Dab2IP of different molecular weights have been described $[28,29]$, which is consistent with our results.

To examine the spatial distribution of Dab2IP, we performed LacZ staining using Dab2IP heterozygous mice at different ages. In these mice, LacZ protein is expressed under the endogenous Dab2IP promoter, thereby providing a histological marker [ $\beta$-galactosidase (gal) staining] to determine Dab2IP promoter activity. At E12 and E14, Dab2IP expression was detected in the cerebral cortex, trigeminal ganglion and cartilaginous tissues (fig. 1Ba, $\mathrm{Bb})$. Dab2IP was highly expressed in various brain structures from embryonic ages to adulthood (fig. $1 \mathrm{Bc}-\mathrm{Bh}$ ). At E12, cells in the cortical plate appeared to express high levels of Dab2IP compared to cells in the ventricular zone (fig. 1Bi). At E14, Dab2IP was strongly detected in cells in the intermediate zone (fig. 1Bj) and at E16, and high expression of Dab2IP was observed in the intermediate zone and cortical plate. Reduced levels of Dab2IP were also present in the ventricular zone (fig. 1Bk). All cortical layers expressed Dab2IP after birth (fig. 1Bk-Bn). Notably, Dab2IP was also expressed in layer I at all postnatal ages (fig. $1 \mathrm{Bm}, \mathrm{Bn}$ ).

To investigate the subcellular localization of the Dab2IP protein in the developing cortex, we performed immunohistochemistry to frozen sections of E14 cerebral cortex using anti-Dab2IP antibody (fig. 2A). Consistent with the $\beta$-gal staining above, Dab2IP was highly expressed in many cells in the intermediate zone and fewer cells in the cortical plate (fig. 2A). Higher-magnification images revealed that Dab2IP protein is localized in the leading process and soma of migrating neurons (fig. 2B). Similar intercellular distribution patterns of Dab2IP were observed in cultured E14 cortical neurons (fig. 2Ca-Cf). Dab2IP protein highly accumulated in the shafts of neurites and adjacent cytoplasmic regions of neurons with processes.

\section{Dab2IP Is Required for Migration of a Subset of Late-Born Neurons in the Developing Cortex}

In the neocortex, the position and fate of a neuron are strongly correlated with its birth date and subsequent migration pattern. The onset of Dab2IP expression in postmitotic migrating neurons (fig. $1 \mathrm{Bj}$ ) suggested that Dab2IP may play a role in the migration of cortical neurons. To test this hypothesis, we performed BrdU-labeling experiments at different developmental time points. Following BrdU injections at E12.5, WT animals exhibited the most heavily BrdU-labeled cells in the inner location of the cortex when analyzed at P21 (fig. 3A). A similar BrdU-labeling pattern was observed in Dab2IP-KD 


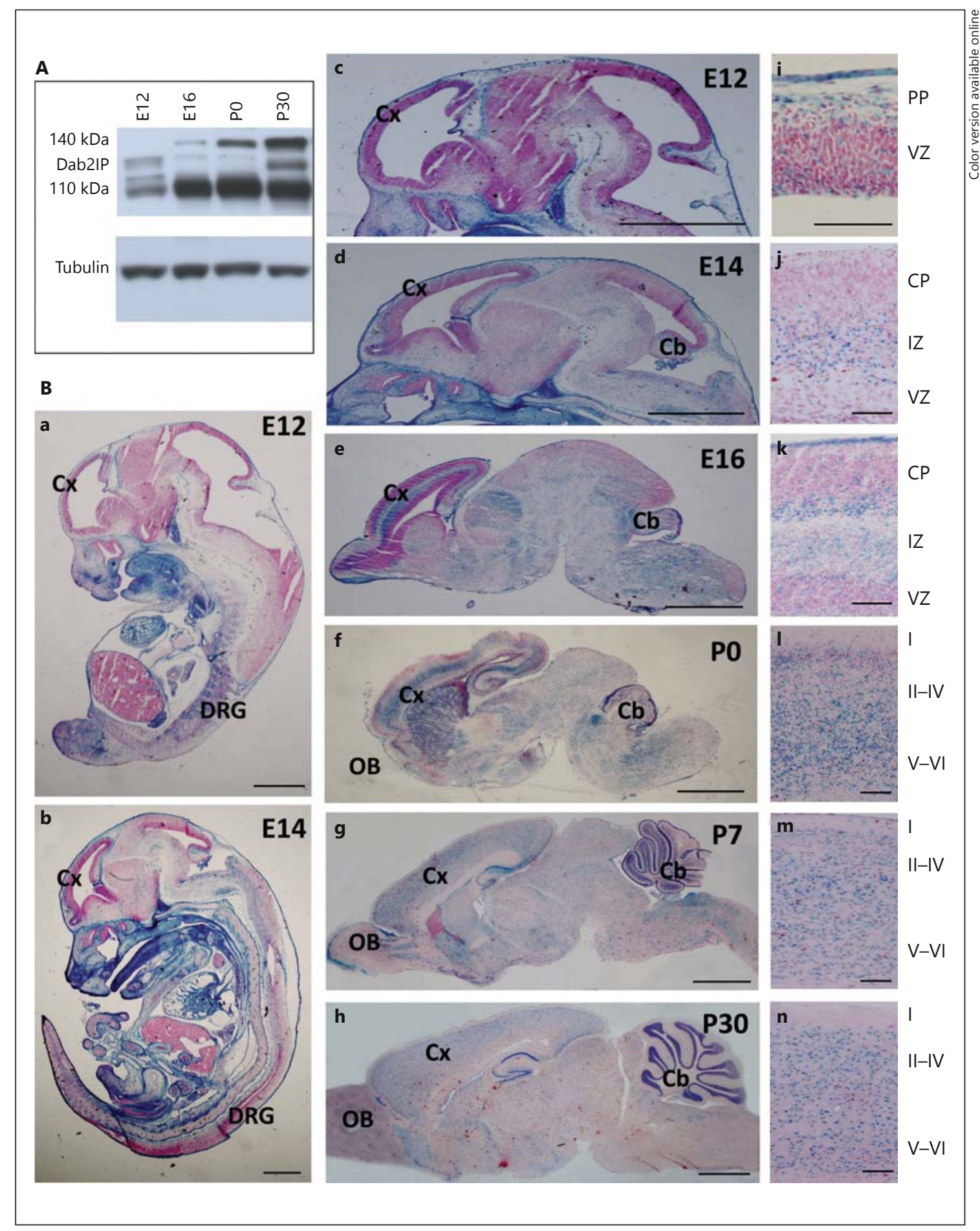

Fig. 1. Expression of the Dab2IP gene in the developing mouse brain. A Western blot analysis of Dab2IP expression. B Sagittal sections of E12 and E14 embryos $(\mathbf{a}, \mathbf{b})$ or of brains from E12 to P30. $\mathbf{a}-\mathbf{h}$ Sections were hybridized with $\beta$-gal and counterstained with nuclear Fast Red. Cx = Cerebral cortex; DRG = dorsal root gan- glion; $\mathrm{Cb}=$ cerebellum; $\mathrm{OB}=$ olfactory bulb. Scale bars: $1.0 \mathrm{~mm}$. i-n Higher-magnification images of $\mathbf{c}-\mathbf{h}$ around the cerebral cortices. $\mathrm{PP}=$ Preplate; $\mathrm{VZ}=$ ventricular zone; $\mathrm{CP}=$ cortical plate; $\mathrm{IZ}=$ intermediate zone; $\mathrm{WM}=$ white matter; II/VI = the layer of the cerebral cortex. Scale bars $=50 \mu \mathrm{m}$. 
Fig. 2. Expression of Dab2IP in E14 mouse brain. A Dab2IP localization visualized with anti-Dab2IP antibody using E14 mouse cerebral cortex coronal sections. B Boxed area in A. Some cell shapes are highlighted with dotted lines. C (a-f) Primary cultured neurons derived from E14 cerebral cortex. Cells were stained with anti-Dab2IP monoclonal antibody (a, d) and phalloidin $(\mathbf{b}, \mathbf{e})$. Scale bars $=25 \mu \mathrm{m}(\mathbf{A}) ; 10$ $\mu \mathrm{m}(\mathbf{B})$, and $10 \mu \mathrm{m} \mathrm{C}(\mathbf{a}-\mathbf{f}) . \mathrm{CP}=$ Cortical plate; IZ = intermediate zone; $\mathrm{VZ}=$ ventricular zone.

Dab2IP Regulates Neuronal Migration, Rap1 and Integrin

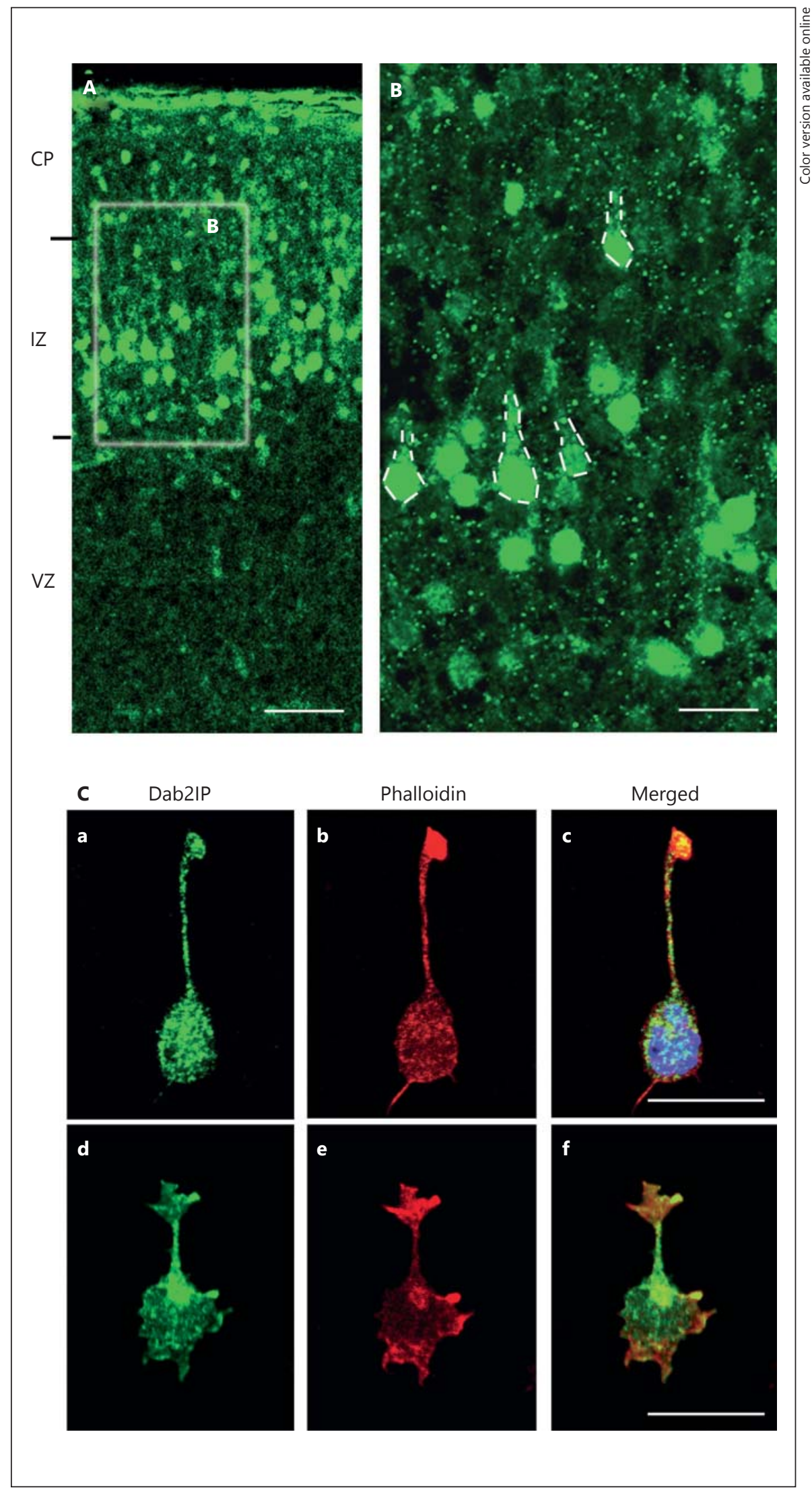

Dev Neurosci 2015;37:131-141 


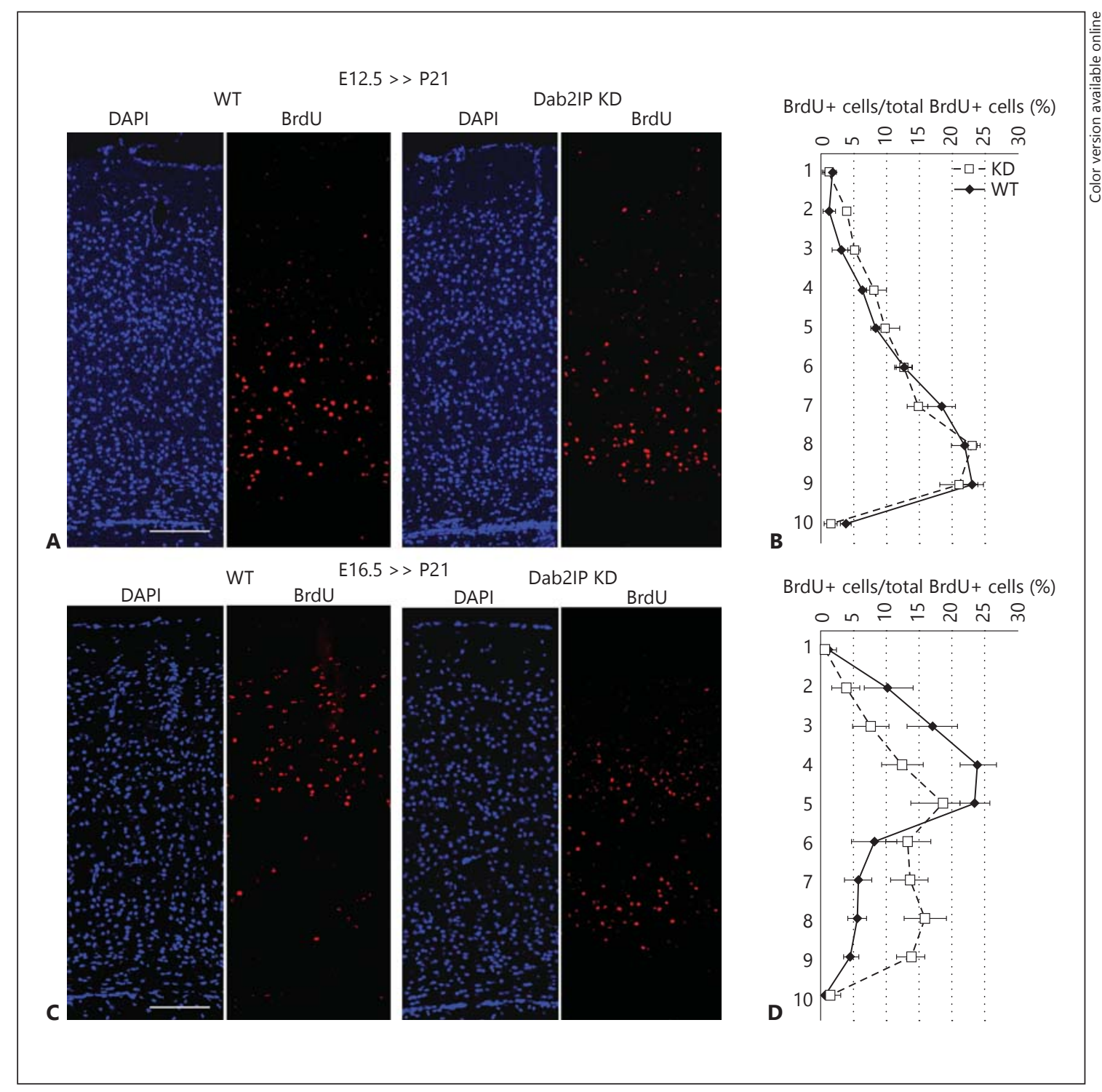

Fig. 3. Dab2IP controls positioning of late-born neurons in the cortex. A, C BrdU labeling was performed at E12 (top panels) or E16 (lower panels) followed by immunostaining for BrdU at P21. B, D Quantification of BrdU-positive cells in each of 10 bins span-

cerebral cortex. We found no quantitative differences in the position of early-born neurons between WT and Dab2IP-KD mice (fig. 3B). When BrdU was injected at E16.5 (to label late-born neurons), we found that some BrdU-labeled neurons were misplaced in Dab2IP-KD animals compared to WT controls (fig. 3C, D). These results suggest that Dab2IP regulates neuronal migration of a specific cohort of late-born neurons.

To investigate if Dab2IP deficiency disrupts migration of neurons in a layer-specific manner, we performed im- ning across the cortex. Graphs show the distribution of BrdU-positive cells in WT (solid lines) and Dab2IP-KD (dashed lines) brains. Data represent means \pm SD using three independent animals for each genotype. Scale bars $=100 \mu \mathrm{m}$ munohistochemical studies (fig. 4). The transcription factor Tbr1 is strongly expressed in cortical layer VI neurons, which are found in E12-E13 in mice [30]. On the other hand, transcription factors Cux 1 (layers II-IV) and Brn-2 (layers II/III and partially V) are specifically expressed in neurons born around E16 [31]. Consistent with our birth dating experiments above, we found Tbr1positive neurons were positioned in the inner part of the cortex in both WT and Dab2IP-KD mice at P21 (fig. 4). In contrast, Cux 1 staining was reduced in the upper cor- 
Fig. 4. A KD of Dab2IP results in mislocalization of late-born cortical neurons. Coronal sections of P21 WT and Dab2IP-KD neocortex (at the level of the hippocampus) were stained with layer-specific markers Tbr1 (layers V/VI), Cux1 (layers II-IV) and Brn-2 (layers II/III, part V). Scale bars $=50 \mu \mathrm{m}$. B Quantification of layerspecific marker immunoreactivity at P30. Graphs depict the percentage and SEM of positive cells in each of ten equal-sized vertical bins for WT (solid lines) and Dab2IP $\mathrm{KD}$ (dashed lines). Approximate positions of cortical layers are identified by alternating gray- and white-shaded areas.

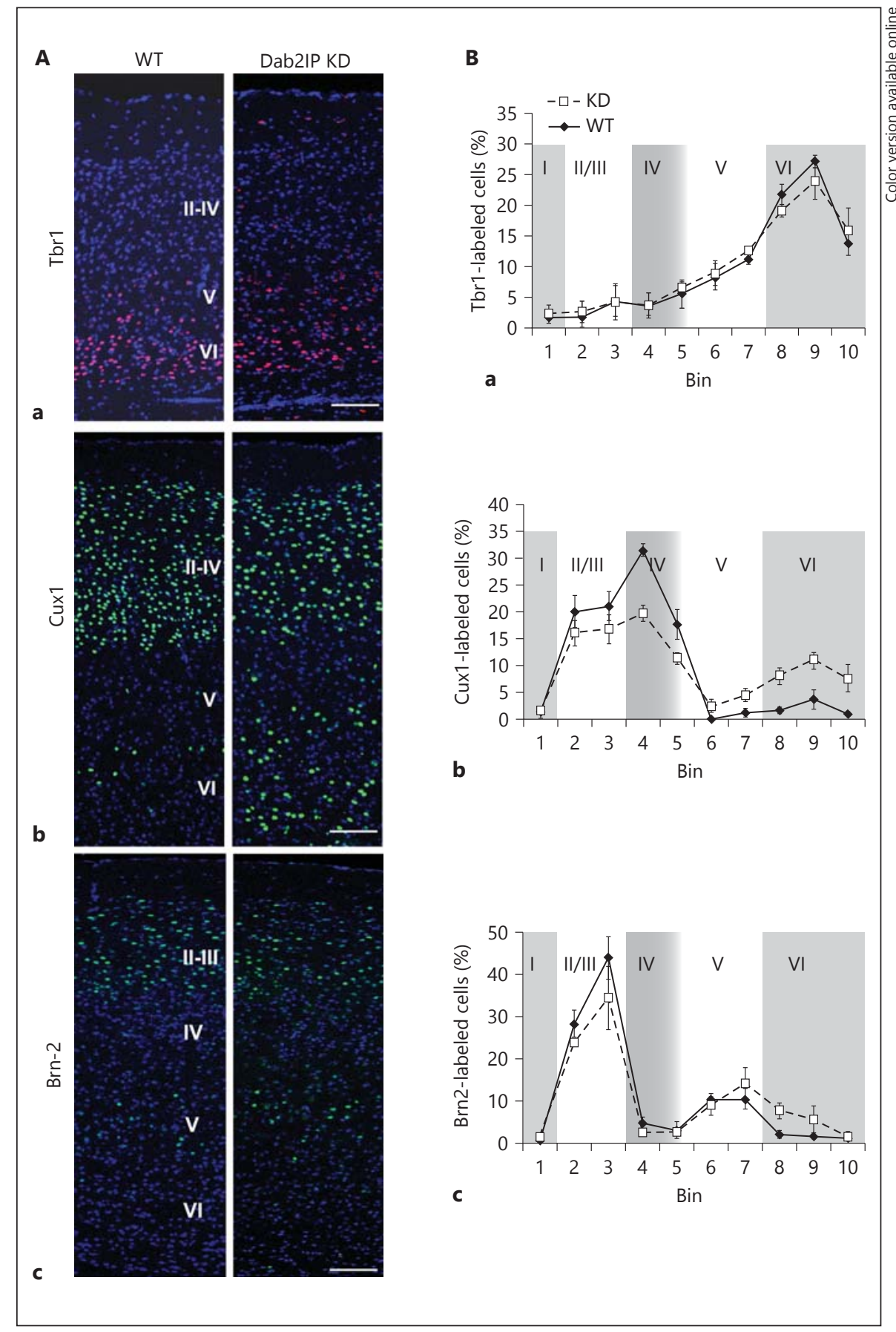

Dab2IP KD Increases Activation of Rap1 and

Integrin $\beta_{1}$

Previous studies demonstrated that early-born neurons destined to be in the deep cortical layers migrate preferentially by somal translocation. On the other hand, late-born neurons destined to be in the upper cortical layers proceed in three phases: multipolar transition, radial 


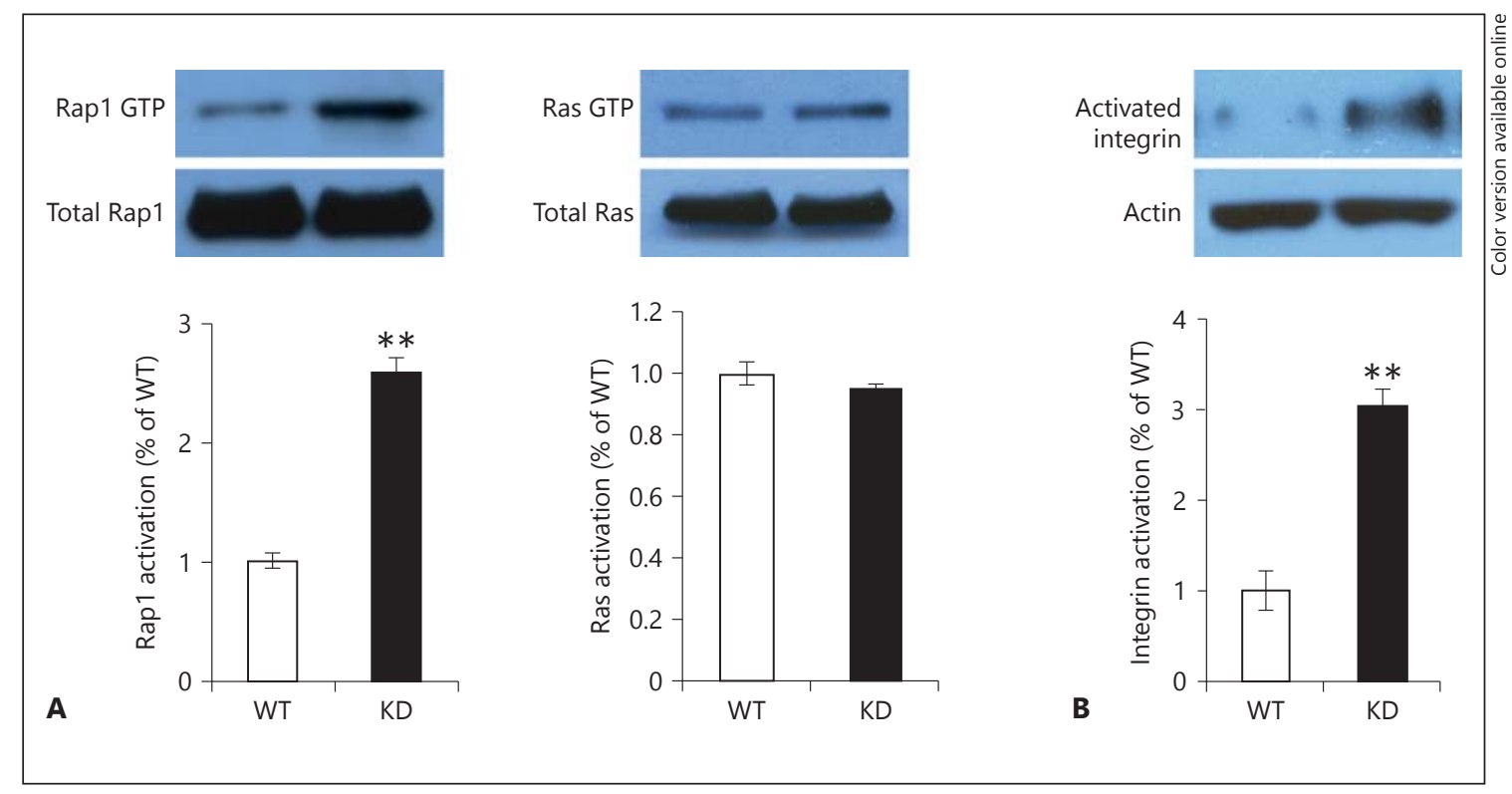

Fig. 5. Dab2IP deficiency causes increased Rap1 and $\beta_{1}$-integrin activation. A Activated Rap1 or Ras in E16 cortical lysates was pulled down using GST-RalGDS-RBD or GST-Raf1-RBD and detected by immunoblotting using anti-Rap1, anti-Ras antibody. Total Rap1 or Ras in the brain lysate was examined by immunoblotting (bottom panel). B Activated $\beta_{1}$-integrin was examined in E16 cortical lysates using 9EG7 antibody. Actin levels were examined

translocation along glial fibers and somal translocation. Lee et al. [26] showed that siRNA-mediated KD of Dab2IP inhibited multipolar to bipolar transition. Other studies suggest that Rap1 activity is required for multipolar transition and proper cortical plate targeting $[7,15]$. To investigate whether Dab2IP regulates Rap1 activity in the developing cortex, we measured activated Rap1 levels via its binding to a Rap1 binding domain, RalGDS-RBD, using E16 WT and Dab2IP-KD cortical lysates. We found a significant ( $\mathrm{p}<0.01, \mathrm{n}=3$, paired $\mathrm{t}$ test) increase in activated Rap1 levels in Dab2IP-KD mice compared to WT controls (fig. 5A). Previous reports have shown that Dab2IP is an Ras-specific GTPase-activating protein in other systems $[22,28]$. Therefore, we also examined Ras activation in Dab2IP-KD brains compared to WT controls. We found no significant difference in activated Ras levels in brain lysates from WT and Dab2IP-KD animals (fig. 5A). These results suggest that Dab2IP specifically regulates Rap1 activity in the developing cortex.

Rap1 plays an important role in the final somal translocation phase of migrating late-born neurons through Reelin-induced activation of $\alpha_{5} \beta_{1}$-integrin signaling and increased adhesion to fibronectin $[7,16]$. Immunoblot in the same lysates as control. Band intensities were quantified using ImageJ software. The relative amount of activated Rap1, Ras and $\beta_{1}$-integrin in Dab2IP KD was compared to WT levels, which were set to 1 . Each bar represents the mean relative intensity \pm SD. Each experiment was performed on multiple littermates. ${ }^{* *} \mathrm{p}<$ 0.01 by paired t test, $n=3$ for Rap 1 , Ras activation assay and $n=4$ for integrin assay. analysis of cortical lysates from E16 WT and Dab2IP-KD mice revealed a significant $(\mathrm{p}<0.01, \mathrm{n}=4$, paired $\mathrm{t}$ test) increase in activated $\beta_{1}$-integrin levels in Dab2IP-KD mice (fig. 5B). These results suggest that Dab2IP also regulates integrin activation, which is required for terminal translocation of late-born cortical neurons.

\section{Discussion}

In this study, we have shown that Dab2IP is abundantly expressed in developing mouse cortex and regulates migration and positioning of a subpopulation of lateborn neurons, possibly through Rap1 regulation. We demonstrated that Dab2IP KD does not affect migration and positioning of early-born neurons, as Tbr1-positive cells were correctly positioned in the Dab2IP-KD mice. Similarly, our birth dating studies showed that early-born neurons migrated correctly, whereas a subset of neurons born at E16.5 did not (fig. 3). Further examination of lateborn neurons using layer-specific markers revealed that Dab2IP KD causes a subset of Cux1-positive neurons (destined to form layers II-IV of the mature cortex to be 
misplaced in deeper layers). Also, a subset of Brn-2-positive cells (destined for layers II/III) were misplaced in deep cortical layers in Dab2IP-KD mice (fig. 4). These data indicate that migration of late-born neurons is not completely disrupted in Dab2IP-KD mice. Many Cux1and Brn-2-positive cells migrated normally.

Although Rap1 appears to have multiple roles during early and late cortical development, our results indicate that downregulation of Rap1 signaling by Dab2IP is important only in later stages of cortical development. The temporal and spatial regulation of Rap1 is critical for its cell signaling function. As with other small GTPase signaling molecules, Rap1 cycles between an inactive GDPbound and an active GTP-bound conformation. Whereas GEFs such as C3G activate Rap1 signaling by stimulating replacement of GTP with GDP, multiple GTPase activating proteins (GAPs) inhibit Rap1 signaling by stimulating the rate of GTP hydrolysis. Thus, subcellular localization of GEFs and GAPs and their specific interactions with different signaling pathways play an important role in temporal and spatial regulation of Rap1 and consequently different aspects of cortical development. Although Dab2IP is expressed in preplate neurons at E12 (fig. 1Ci), CSPG staining revealed that the preplate splits normally in Dab2IP-KD mice (online suppl. fig. 1; for all online suppl. material, see www.karger.com/ doi/10.1159/000369092). This is in sharp contrast to the defects observed in mice lacking Rap1 activator C3G, which fail to split the preplate and show defects in radial glial attachment as well as neuronal migration [32].

Dab2IP was originally characterized as an Ras-specific GTPase-activating protein $[22,28]$. However, our data provide the first evidence that Dab2IP also regulates Rap 1 GTPase in vivo. We have shown that Dab2IP deficiency enhanced Rap1 activation in E16.5 brain (fig. 5A), whereas it did not affect Ras activation at this age (fig. 5A). Based on these results, we conclude that Dab2IP may be a dual-specific GAP protein. A number of different GAP proteins have been identified with specificity toward either Ras or Rap1, depending on the presence of an arginine finger in their catalytic domain [33]. However, recent studies have identified a family of RasGAPs which also have Rap1GAP activity, such as GAP $1^{1 \mathrm{P} 4 \mathrm{BP}}$, CAPRI, Rasal and SynGAP [34-37]. These dual-specific GAPs share structural similarity with Dab2IP in that they contain conserved Pleckstrin homology and C2 domains near their catalytic GAP domain. Studies have shown the presence of these domains contribute to Ras and Rap1 specificity by regulating their subcellular localization which determines accessibility to Ras and Rap1 proteins, as well as by directly modulating the catalytic domain of GAPs $[34,38]$. For instance the C2 domain of Rasal mediates lipid binding and confers Rap1GAP specificity [38]. Deletion of the Rasal C2 domain reduced its Rap1GAP activity 1,000-fold but only reduced its RasGAP activity 6-fold [34]. It is interesting to note that different isoforms of SynGAP, varying in their $\mathrm{PH}$ domain and C-terminal protein interaction domains, exert opposing effects on synaptic plasticity [39]. This is consistent with the notion that Rap1 and Ras have opposing functions in different cell systems. Dab2IP is structurally very similar to SynGAP and we have shown that different protein isoforms of Dab2IP exist in the developing brain (fig. 1). Thus, we speculate that the dual specificity of Dab2IP may in part be defined by the presence of different domains. Further molecular experiments will be necessary to investigate this hypothesis.

Reelin plays an important role in multiple phases of migration in late-born cortical neurons through activation of the CrkL/C3G/Rap1 signaling pathway. Reelininduced Rap 1 signaling is required for $\mathrm{N}$-cadherin-mediated bipolar orientation of migrating neurons as well as integrin-mediated fibronectin adhesion required for terminal translocation $[7,15,16]$. Several groups have shown that both inhibition and excessive activation of Rap1 disrupt migration of cortical neurons, indicating that finetuned regulation of Rap1 is necessary for proper migration $[7,16,26]$. Consistent with these observations, we previously found that siRNA-mediated downregulation of Dab2IP as well as overexpression of Dab2IP inhibited migration of cortical neurons using an in utero electroporation approach [26]. In this study, we showed that disruption of the Dab2IP gene also inhibits migration of some, but not all, late-born cortical neurons. Moreover, Dab2IP deficiency resulted in enhanced activation of Rap1 as well as $\beta_{1}$-integrin signaling (fig. 5 ). It will be important to investigate precisely how Dab2IP may be involved in various aspects of Reelin signaling during cortical development.

\section{Acknowledgments}

We thank Dr. Lynn A. Jones for assistance with the animal colonies. This work was supported by NIH MH068433 and the Assisi Foundation of Memphis.

\section{Disclosure Statement}

The authors have no conflict of interest to declare. 


\section{References}

$>1$ Rakic P: Evolution of the neocortex: a perspective from developmental biology. Nat Rev Neurosci 2009;10:724-735.

-2 Nadarajah B, Brunstrom JE, Grutzendler J, Wong RO, Pearlman AL: Two modes of radial migration in early development of the cerebral cortex. Nat Neurosci 2001;4:143-150.

-3 Tabata H, Nakajima K: Multipolar migration: the third mode of radial neuronal migration in the developing cerebral cortex. J Neurosci 2003;23:9996-10001.

4 Tabata H, Kanatani S, Nakajima K: Differences of migratory behavior between direct progeny of apical progenitors and basal progenitors in the developing cerebral cortex. Cereb Cortex 2009; 19:2092-2105.

$\checkmark 5$ Noctor SC, Martinez-Cerdeno V, Ivic L, Kriegstein AR: Cortical neurons arise in symmetric and asymmetric division zones and migrate through specific phases. Nat Neurosci 2004;7:136-144.

6 Shoukimas GM, Hinds JW: The development of the cerebral cortex in the embryonic mouse: an electron microscopic serial section analysis. J Comp Neurol 1978;179:795-830.

7 Franco SJ, Martinez-Garay I, Gil-Sanz C, Harkins-Perry SR, Muller U: Reelin regulates cadherin function via Dab1/Rap1 to control neuronal migration and lamination in the neocortex. Neuron 2011;69:482-497.

>8 Sekine K, Honda T, Kawauchi T, Kubo K, Nakajima K: The outermost region of the developing cortical plate is crucial for both the switch of the radial migration mode and the Dab1-dependent 'inside-out' lamination in the neocortex. J Neurosci 2011;31:9426-9439.

>9 D’Arcangelo G, Homayouni R, Keshvara L, Rice DS, Sheldon M, Curran T: Reelin is a ligand for lipoprotein receptors. Neuron 1999; 24:471-479.

-10 Hiesberger T, Trommsdorff M, Howell BW, Goffinet A, Mumby MC, Cooper JA, Herz J: Direct binding of Reelin to VLDL receptor and ApoE receptor 2 induces tyrosine phosphorylation of disabled-1 and modulates tau phosphorylation. Neuron 1999;24:481-489.

$\checkmark 11$ Arnaud L, Ballif BA, Forster E, Cooper JA: Fyn tyrosine kinase is a critical regulator of disabled-1 during brain development. Curr Biol 2003;13:9-17.

12 Bock HH, Herz J: Reelin activates SRC family tyrosine kinases in neurons. Curr Biol 2003; 13:18-26.

$>13$ Ballif BA, Arnaud L, Arthur WT, Guris D, Imamoto A, Cooper JA: Activation of a Dab1/ CrkL/C3G/Rap1 pathway in Reelin-stimulated neurons. Curr Biol 2004;14:606-610.

$\checkmark 14$ Bock HH, Jossin Y, Liu P, Forster E, May P, Goffinet AM, Herz J: Phosphatidylinositol 3-kinase interacts with the adaptor protein Dab1 in response to Reelin signaling and is required for normal cortical lamination. J Biol Chem 2003;278:38772-38779.

$>15$ Jossin Y, Cooper JA: Reelin, Rap1 and N-cadherin orient the migration of multipolar neu- rons in the developing neocortex. Nat Neurosci 2011;14:697-703.

-16 Sekine K, Kawauchi T, Kubo K, Honda T, Herz J, Hattori M, Kinashi T, Nakajima K: Reelin controls neuronal positioning by promoting cell-matrix adhesion via inside-out activation of integrin alpha5beta1. Neuron 2012;76:353-369.

17 Gil-Sanz C, Franco SJ, Martinez-Garay I, Espinosa A, Harkins-Perry S, Muller U: CajalRetzius cells instruct neuronal migration by coincidence signaling between secreted and contact-dependent guidance cues. Neuron 2013;79:461-477.

18 Homayouni R, Magdaleno S, Keshvara L, Rice DS, Curran T: Interaction of Disabled-1 and the GTPase activating protein Dab2IP in mouse brain. Brain Res Mol Brain Res 2003; 115:121-129.

19 Duggan D, Zheng SL, Knowlton M, Benitez D, Dimitrov L, Wiklund F, Robbins C, Isaacs SD, Cheng Y, Li G, Sun J, Chang BL, Marovich L, Wiley KE, Balter K, Stattin P, Adami HO, Gielzak M, Yan G, Sauvageot J, Liu W, Kim JW, Bleecker ER, Meyers DA, Trock BJ, Partin AW, Walsh PC, Isaacs WB, Gronberg H, Xu J, Carpten JD: Two genome-wide association studies of aggressive prostate cancer implicate putative prostate tumor suppressor gene DAB2IP. J Natl Cancer Inst 2007;99:18361844.

20 Gretarsdottir S, Baas AF, Thorleifsson G, Holm H, den Heijer M, de Vries JP, Kranendonk SE, Zeebregts CJ, van Sterkenburg SM, Geelkerken RH, van Rij AM, Williams MJ, Boll AP, Kostic JP, Jonasdottir A, Walters GB, Masson G, Sulem P, Saemundsdottir J, Mouy M, Magnusson KP, Tromp G, Elmore JR, Sakalihasan N, Limet R, Defraigne JO, Ferrell RE, Ronkainen A, Ruigrok YM, Wijmenga C, Grobbee DE, Shah SH, Granger CB, Quyyumi AA, Vaccarino V, Patel RS, Zafari AM, Levey AI, Austin H, Girelli D, Pignatti PF, Olivieri O, Martinelli N, Malerba G, Trabetti E, Becker LC, Becker DM, Reilly MP, Rader DJ, Mueller T, Dieplinger B, Haltmayer M, Urbonavicius S, Lindblad B, Gottsater A, Gaetani E, Pola R, Wells P, Rodger M, Forgie M, Langlois N, Corral J, Vicente V, Fontcuberta J, Espana F, Grarup N, Jorgensen T, Witte DR, Hansen T, Pedersen O, Aben KK, de Graaf J, Holewijn S, Folkersen L, Franco-Cereceda A, Eriksson P, Collier DA, Stefansson H, Steinthorsdottir V, Rafnar T, Valdimarsson EM, Magnadottir HB, Sveinbjornsdottir S, Olafsson I, Magnusson MK, Palmason R, Haraldsdottir V, Andersen K, Onundarson PT, Thorgeirsson G, Kiemeney LA, Powell JT, Carey DJ, Kuivaniemi H, Lindholt JS, Jones GT, Kong A, Blankensteijn JD, Matthiasson SE, Thorsteinsdottir U, Stefansson K: Genomewide association study identifies a sequence variant within the DAB2IP gene conferring susceptibility to abdominal aortic aneurysm. Nat Genet 2010;42:692-697.
21 Harrison SC, Cooper JA, Li K, Talmud PJ, Sofat R, Stephens JW, Hamsten A, Sanders J, Montgomery H, Neil A, Humphries SE: Association of a sequence variant in DAB2IP with coronary heart disease. Eur Heart J 2012;33:881-888.

22 Chen H, Pong RC, Wang Z, Hsieh JT: Differential regulation of the human gene DAB2IP in normal and malignant prostatic epithelia: cloning and characterization. Genomics 2002;79:573-581.

23 Zhang H, Zhang R, Luo Y, D'Alessio A, Pober JS, Min W: AIP1/DAB2IP, a novel member of the Ras-GAP family, transduces TRAF2-induced ASK1-JNK activation. J Biol Chem 2004;279:44955-44965.

24 Chang SL, Chou RH, Zeng HJ, Lin YH, Chiu TY, Yang DM, Hung SC, Lai CH, Hsieh JT, Shyu WC, Yu YL: Downregulation of DAB2IP promotes mesenchymal-to-neuroepithelial transition and neuronal differentiation of human mesenchymal stem cells. PLoS One 2013; 8:e75884.

25 Xie D, Gore C, Liu J, Pong RC, Mason R, Hao G, Long M, Kabbani W, Yu L, Zhang H, Chen H, Sun X, Boothman DA, Min W, Hsieh JT: Role of DAB2IP in modulating epithelial-tomesenchymal transition and prostate cancer metastasis. Proc Natl Acad Sci U S A 2009; 107:2485-2490.

-26 Lee GH, Kim SH, Homayouni R, D’Arcangelo G: Dab2ip regulates neuronal migration and neurite outgrowth in the developing neocortex. PLoS One 2012;7:e46592.

$\checkmark 27$ Qiao S, Kim SH, Heck D, Goldowitz D, LeDoux MS, Homayouni R: Dab2IP GTPase activating protein regulates dendrite development and synapse number in cerebellum. PLoS One 2013;8:e53635.

28 Wang Z, Tseng CP, Pong RC, Chen H, McConnell JD, Navone N, Hsieh JT: The mechanism of growth-inhibitory effect of DOC-2/ $\mathrm{DAB} 2$ in prostate cancer. Characterization of a novel GTPase-activating protein associated with N-terminal domain of DOC-2/DAB2. J Biol Chem 2002;277:12622-12631.

29 Chen H, Karam JA, Schultz R, Zhang Z, Duncan C, Hsieh JT: Cloning of mouse Dab2ip gene, a novel member of the RasGTPase-activating protein family and characterization of its regulatory region in prostate. DNA Cell Biol 2006;25:232-245.

30 Englund C, Fink A, Lau C, Pham D, Daza RA, Bulfone A, Kowalczyk T, Hevner RF: Pax6, Tbr2, and Tbr1 are expressed sequentially by radial glia, intermediate progenitor cells, and postmitotic neurons in developing neocortex. J Neurosci 2005;25:247-251.

31 Molyneaux BJ, Arlotta P, Menezes JR, Macklis JD: Neuronal subtype specification in the cerebral cortex. Nat Rev Neurosci 2007;8:427-437.

-32 Voss AK, Britto JM, Dixon MP, Sheikh BN, Collin C, Tan SS, Thomas T: C3G regulates cortical neuron migration, preplate splitting and radial glial cell attachment. Development 2008;135:2139-2149. 
33 Raaijmakers JH, Bos JL: Specificity in Ras and Rap signaling. J Biol Chem 2009;284:1099510999.

-34 Sot B, Kotting C, Deaconescu D, Suveyzdis Y, Gerwert K, Wittinghofer A: Unravelling the mechanism of dual-specificity gaps. EMBO J 2010;29:1205-1214.

35 Kupzig S, Deaconescu D, Bouyoucef D, Walker SA, Liu Q, Polte CL, Daumke O, Ishizaki T, Lockyer PJ, Wittinghofer A, Cullen PJ: GAP1 family members constitute bifunctional Ras and Rap GTPase-activating proteins. J Biol Chem 2006;281:9891-9900.
36 Kupzig S, Bouyoucef-Cherchalli D, Yarwood S, Sessions R, Cullen PJ: The ability of GAP1IP4BP to function as a Rap1 GTPaseactivating protein (GAP) requires its Ras GAP-related domain and an arginine finger rather than an asparagine thumb. Mol Cell Biol 2009;29:3929-3940.

37 Pena V, Hothorn M, Eberth A, Kaschau N, Parret A, Gremer L, Bonneau F, Ahmadian MR, Scheffzek K: The C2 domain of SynGAP is essential for stimulation of the Rap GTPase reaction. EMBO Rep 2008;9:350-355.
38 Sot B, Behrmann E, Raunser S, Wittinghofer A: Ras GTPase activating (RasGAP) activity of the dual specificity GAP protein Rasal requires colocalization and $\mathrm{C} 2$ domain binding to lipid membranes. Proc Natl Acad Sci U S A 2013;110:111-116.

-39 McMahon AC, Barnett MW, O'Leary TS, Stoney PN, Collins MO, Papadia S, Choudhary JS, Komiyama NH, Grant SG, Hardingham GE, Wyllie DJ, Kind PC: SynGAP isoforms exert opposing effects on synaptic strength. Nat Commun 2012;3:900. 